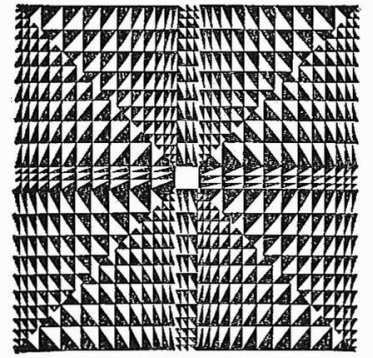

1.はじめに

(TMTSF) $)_{2}$ X中心とした有機超伝導体の物理和よ び化学的な理解は急速に進み, 超伝導の機構や分子設 計も詳しく議諭されるようになってきたままた斉藤ら によって開発された新しい有機超伝導体 (BEDTTTF $)_{2} \mathrm{X}$ 系の研究む活発になり，かなり高い $T_{\mathrm{c}}$ の超 伝導体も合成されている.これらの有機超伝導体に関 してはすでにいくつかの優れた解説が書かれているの で1) 4)，ここではもっと広く上記の解説とは異なった 見地から，新しい有機伝導体への道をさぐってみる.

約 10 年活ど前, TTF-TCNQ が organic metal として登場し，低温で半導体に轱移することが見い出 された．これは，1次元金属特有のパイエルス転移と 夕なされた、われわれは，高圧下で鎖間相互作用を強 めて $2 \sim 3$ 次元性を増加させ, 極低温まで金属状態を 保持できれば超伝導が現われると考克, 極低温用超高 圧発生装置を開発した。残念ながら TTF-TCNQ, $\mathrm{K}_{2} \mathrm{Pt}(\mathrm{CN})_{4} \mathrm{Br}_{0.3}-3 \mathrm{H}_{2} \mathrm{O}(\mathrm{KCP})$, ( $(\mathrm{CH})_{x} \mathrm{X}_{n}$ „で超伝導は 観測されなかっだ . Bechgaardや Jerome たちが (TMTSF $)_{2} \mathrm{PF}_{6}$ 学合成し, 静水圧下で有機物䐝で初め て超伝導を発見したのは記憶倍しい(6).われわれの 失敗は, TTF-TCNQ では 1 次元性が強いので高い圷 力が必要と考克，压力媒体火固体を用いたことにあ る. 固体压縮法は超高压発生優れているが, 静水圧 性が低下するため固相反応を誘発したり，単結晶を割 ったりする弊害がある。この技術は後に生かされ黒り ンの與味深い超伝導の発見につながっだ).

すでに合成された有機超伝導体の化学的特徴は Sや Se を含んだフルバレン骨格をもっている: この骨格 を変えなければ細い分子設計が可能で, かなり多くの 有機超伝導体が合成されるようになっだ2. しかしフ ルバレン骨格以外の有機超伝導体はまだ合成されてい ない.これはなぜなのか, 結果からの考察は可能です

New Organic Superconductor
るが，詳しいことはまだわかっていない，有機超伝導 体にはS P S が含まれている. 無機の超伝導体も $\mathrm{S}$ p Se の化合物が多い，Nb は高い $T_{\mathrm{e}}$ をるつ金属 で, この S, Se 化物の $T_{\mathrm{c}}$ b高い, 一方, ヨウ化物 $\left(\mathrm{NbI}_{4}\right)$ 惊圧下で金属化させても超公導を示さな ( $^{87}$. このように超伝導が現われやすいか否かは元素 にかなり依存して拈り，ただ伝導電子とフォフンさ兄 あれば超伝導が現われる、といった単純なるのでは ない、先れゆ点, 新しい超伝導体の設計は organic metals のそれに比べはるかに難しく，また経験に頼 らざるを党ないのが実情である，分子間相互作用の強 い organic metals を合成して超伝導の有無を詳しく 調べま灷高圧下でいろいろなデータを集積して，有 機超伝導体の設計思想をつくってゅかなければならな W.

Little が励起子メカニズムの高温超伝導体のモデル 化合物としてポリマーをあけ゚たこともありり，導電性 高分子の研究はポリアセチレンをはじめとしてきわめ て活発行なわれているが, 超伝導体はいまだつくり だされていない，励起子メカニズムの高温超伝導体が つくれるかどらか，はっきりしたことをい克る状態で ないが, 最近,われわれは黒リンで異常な超云導を発 見した．ここではこの概観を紹介し，新しい有機超云 導体への展望を述べてみたいと思う。

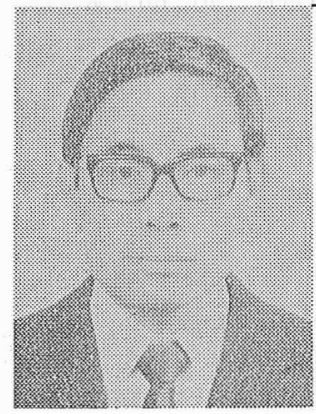

城谷一民 室蘭工業大学エネル ギー工学専攻 $(050$ 室棝市水元 町 27-1) 助教授・理博 昭和 38 年千葉大理学部卒, 40 年東大大学院修士課程修了. 38 年東大物性研超高圧部門入所, 技官, 助手を経て, 58 年室蘭 工大助教授, 玩在《至る. 機能 性祆料の合成之物性，高圧物性 の研究に従事.

〈趣味〉テ二ス, 水泳, 野球, 登山 


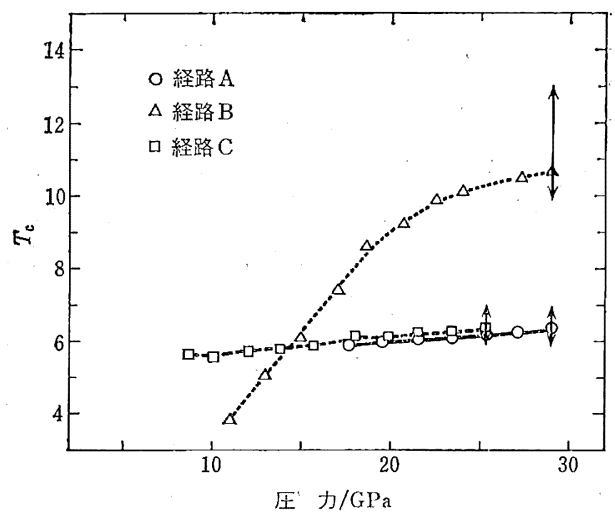

経路 $\mathrm{A}$ : 室温で加圧して単純立方晶（金属相）を つくったあと $4.2 \mathrm{~K}$ に下げた場合

$\mathrm{B}$ : 大気圧下で $4.2 \mathrm{~K}$ まで下げ，そのあと 加圧した場合

C : 室温で菱面体 (七素型) 黒りンをつくっ たあと $4.2 \mathrm{~K}$ に下げ，ささらに加圧した 場合

図 1 黑リンの超伝導䎐移温度 $\left(\boldsymbol{T}_{\mathrm{c}}\right)$ の圧力勏果 ( $1 \mathrm{GPa}=10 \mathrm{kbar}=10^{4} \mathrm{~atm}$ )

\section{2. 黑リンの異常な超伝導}

リンには黄リン, 赤リン, 黑リンの 3 つの同素体が ある.この中で黒リンは化学的汇最も安定で, すでに 結晶構造も層状の斜方晶系であることが知られてい る ${ }^{10)}$ ，黑りン沙単体唯一のギャップのせぬい半導体 で，新しい電子材料として注目されている，われわれ 性高温, 高圧下で 黒りンの大型単結晶の 育成に成功 し, これらの物性研究を進めている ${ }^{11)}$.

大気圧下で斜方晶の黑リンは $4.5 \mathrm{GPa}(45 \mathrm{kbar})$ で 蕧面体晶系（七素型）飞, さら飞約 $9.5 \mathrm{GPa}$ で単純 立方晶系汇变化する ${ }^{122}$ ，転移のさい物性む著しく変わ って, 半導体から半金属そして最後に金属になる.金

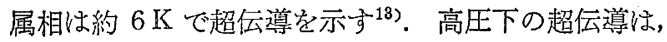
通常, 室温で庄力を上げて単純立方晶（金属相）をつ くり，その後で液体へリウム温度まで下げて測定され る. 低温下での加压は，圧力蝶体がきわめて硬くなる ため圧力が伝わりにくく、一般には行なわれない. TTF-TCNQ で超伝導測定ができなかった最大の理由 は, 室温で加圧するさいに固相反応を伴うためであっ た，極低温下で圧力を可変できれば，多くの興味深い 物性研究が可能になるので, ダイヤモンドアンビルを 用いて極低温下での圧力可变超高圧発生装置を開発し た ${ }^{14)} .4 .2 \mathrm{~K} て ゙ 30 \mathrm{GPa}$ 空で高压発生できる.

黒リン単結晶の超伝導は 3 つの道すじ, 経路 $A, B$, C 従って測定された。経路 $\mathrm{A}$ はすで研究されてい る道すじで，室温で金属相をつくり，そのあと液体一

\author{
$\mathrm{O}_{1}, \mathrm{O}_{2}$ : 斜方晶黒りンの回 \\ 折線 \\ $R_{1}, R_{2}$ : 菱面体晶( 七素型) \\ 黒りンの回折線
}

図 2 高圧下における累リン の粉末 X 線回折

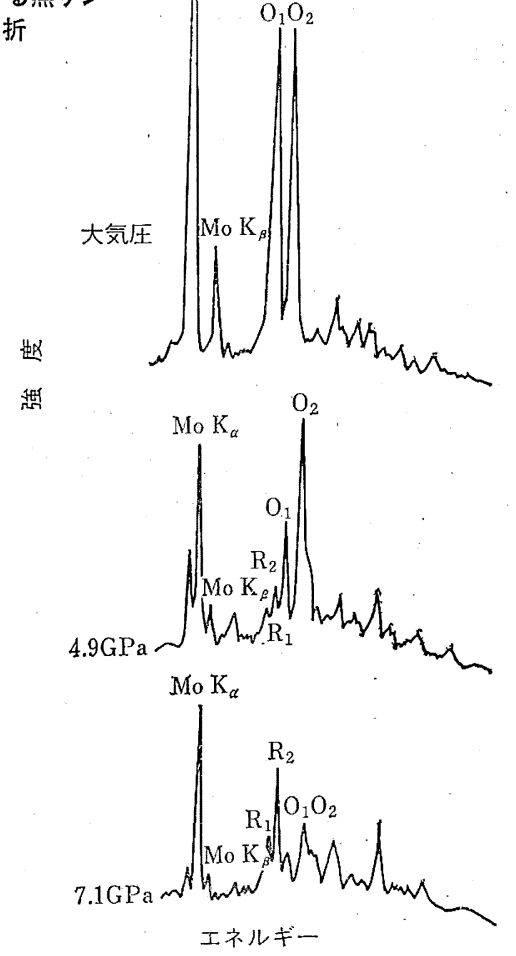

リウムム温度に下げる. 経路 Bは大気圧下で $4.2 \mathrm{~K} に 下$ げたあと加圧する，経路Cは室温で半金属相をつく り， $4.2 \mathrm{~K}$ に下げ，その後圧力を上げて超伝導を測定 した. 図 1 亿 3 つの経路 A，B，C従って测定され た超伝導の $T_{\mathrm{c}}$ の圧力依存性を示す。経路 $\mathrm{A}, \mathrm{C}$ で

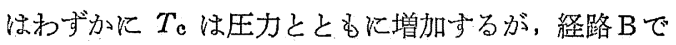
は $T_{\mathrm{c}}$ 隐上昇し, 最高 $13 \mathrm{~K}$ 火も達する。. $T_{\mathrm{c}}$ の圧 力依存性は道すじにより著しく異なっている。一般に 超伝導の $T_{\mathrm{c}}$ は注とんどの物質で圧力の増加とともに 減少する，経路 Bのよらなふるまいはきわめて異例で ある. 遷移金属の中にごくわずか $T_{\mathrm{c}}$ が圧力とともに 急上昇するものが知られているが, 典型元素では初め ての例である.

黒リンの異常な超伝導は 2 回にわたる压力誘起相耺 移の機構と密接関係している ${ }^{15)}$. 図 2 亿斜方晶黒り ンからヒ素型黒リンに相転するさいの粉末 X線回折パ ターンを示す。これはェネルギー分散法によるるので X線源は Mo の白色X線, $2 \theta=16^{\circ}$ 飞固定して測定 された. 斜方晶黑リンは $4.5 \mathrm{GPa}$ 付近で転移を始め, 圧力の増加とともに両相の比率を徐々に変えながら， 
約 $8 \mathrm{GPa}$ で斜方晶は消克, 完全にヒ素型に変わる. このように相転移の速度は大変遅く, 二相共存する圧 力範囲はきわめて広い，高エネルギー研の軌道放射光 を使って， $77 \mathrm{~K}$ 下で黑りンの圧力誘起相転移の研究 を進めているが，少なくとる $11 \mathrm{GPa}$ をでは斜方晶黒 リンの回折パターンが見い出される。極低温下では二 相共存する圧力範囲がさらに広がる，七素型から単純 立方晶への転移は 2 次転移的なため相共存する压力領 域はせ心い，それゆ光，極低温下では半導体相の斜方 晶と金属相の単純立方晶がわずかであれ共存している 可能性が大きい。

図 1 の経路Cをもら一度みていたたききたい，室温で 半金属相をつくって液体へリウム温度に下げたあと加 圧した場合は, 経路 $\mathrm{B}$ のよな $T_{\mathrm{c}}$ の急上昇はみられ ない. 半金属相は $T_{\mathrm{c}}$ の増加対してあ⿱亠巾口寄与して いない，それゆ完，高い $T_{\mathrm{e}}$ の出現には半導体相と金 属相の共存がきわめて重要な役割を果たし，励起子モ デルの超伝導の可能性を示唆している. 共存する半導 体と金属の界面で, 励起子がクーパー対をつくって超

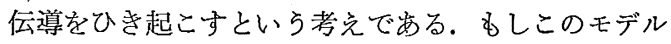
が正しければ将来高温超厷導体る夢ではなくなるであ ろう、残念ながらこれまでの実験だけではそこまで断 言できない，黑リンの異常な超伝導の重要性は, メカ ニズムが BCS 理論炕るのだとしてる, 不均一系 の超伝導だということにある。市る種の不均一性は $T_{\mathrm{c}}$ を引きめげる働きをする，不均一系の超伝導はい ろいろ研究されているが, 通常は化学成分が多成分系 になっている場合である. 黒リンのように単体で, 相 共存している不均一系の超伝導は䌽とんど知られてい ない。

黒リンで観測された超伝導は単純な物質でみられる だけに，黒リン特有の現象ではないと思われる，条件 さえととの党ば他の単体や化合物で, 黒リンと類似の 現象がみられても不思議はない。半導体相と金属相を らまく共存させれば，かなり高い $T_{\mathrm{c}}$ の超伝導体が得 られるだろう、これは新しい超伝導体をつくるら兄で 重要な指針となる，多くの物質は温度や圧力を变える 々半導体一金属転移を起こす. 圧力分布や温度分布を 利用して, 半導体相と金属相を共存させて不均一な状 態をつくれば, 少なくともいままでの $T_{\mathrm{c}}$ の 2 倍くら いは上げられるであるう，もちろん不均一系は準安定 状態であるが，黒リンの上うに転移の速度がきわめて 荤いものを選べば，安定に高い $T_{\mathrm{c}}$ の状態を保つこと が可能である. 夢のような励起子モデルによる高温超 伝導体を考光るのも悪くないが, 不均一系超伝導体を つくって $T_{\mathrm{c}}$ を高めさせるのは，はるかに現実的な話 である.

\section{3. 新しい有機超伝導体}

多くの organic metals が合成されているが, 超伝 導を示すのはフルバレン骨格をもった 10 種程度であ る. Organic metals 強い1 次元性のため低温で半 導体に変わり超伝尊怆ならない，半導体相を加圧し て 2〜3 次元性を増大させれば金属化するので, 超云 導が現われるょうになる.今まで高圧下で測定された 超伝導は約 $1.5 \mathrm{GPa}$ までであるが，もっと圧力範囲 を広げられれば有機超伝導体が増加するはずである。

黒りン同㨾極低温下で加圧し，半導体相と金属相を共 存させた不均一系の新しい超伝導体がつくれれば $T_{\mathrm{c}}$ も上げられる.。

(TMTSF) ${ }_{2} \mathrm{ClO}_{4}$ は大気圧下で超伝導になるが， (TMTSF $)_{2} \mathrm{ReO}_{4}$ では低温で半導体になってしまう. この金属一半導体転移は単純なパイェルス転移ではな く, $\mathrm{ReO}_{4}^{-}$- の秩序一無秩序転移がからんでくる，0.95 $\mathrm{GPa}$ 以上で超伝導が現われるが，普通の超伝導体には みられない抵抗の異常が観湘される ${ }^{16)}$.この物質を極 低温下で加圧すれば，今をでと異なる超伝導る期待で きる. BEDT-TTF 系でソ連のグループが $7 \mathrm{~K}$ の超伝 導を発見したと伝兄られる ${ }^{1}$.これはいろいるな多形 ができやすいため, 西る種の不均一系の超伝導体が生 じている可能性が大きい。これが $T_{\mathrm{c}}$ を高くしている かも知れない。

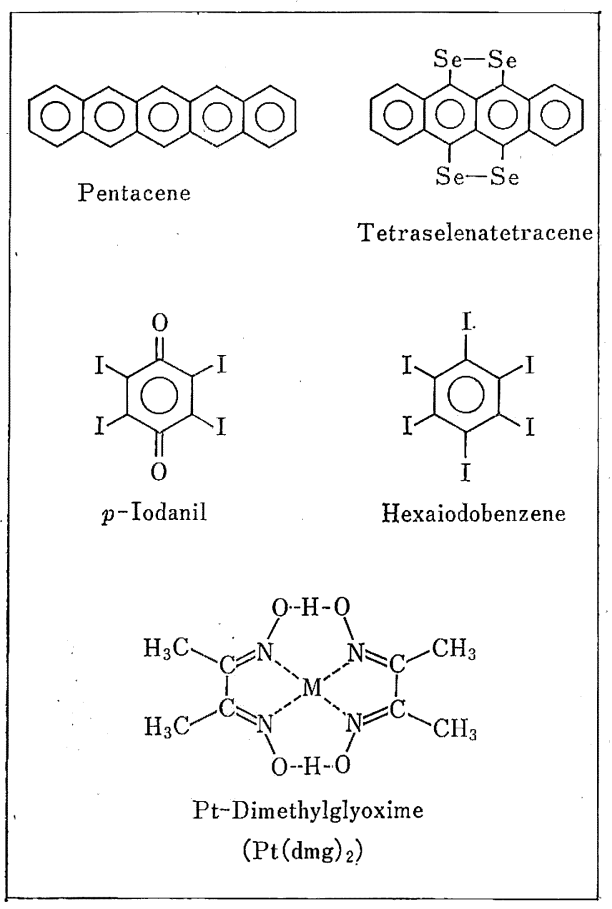

図 3 高圧下で高伝導性になる物犋の分子構造 
フルバレン骨格をもたない organic metals の超伝 導はまだ見い出されていない，これらを超高圧まで加 圧して超伝導を引き出し, 新しい骨格の有機超伝導体 をさがさなければならない。

図 3 にペンタセン, テトラセレナテトラセン, ヨウ ドアニル，ヘキサヨウドベンゼンの分子棈造を示す. 大気圧下でこれらは大きな抵抗值をるつが, 圧力とと もに急激に抵抗を減少させて, $20 \mathrm{GPa}$ 下で約 $0.1 \Omega$. $\mathrm{cm}$ に達する ${ }^{17), 18)}$ ，吸収帯も加圧に伴い大きな red shift を示し，ェネルギーギャップを急減させる。そ れゆ光，芳香族結晶は金属化されたと思われるが，室 温での加圧は $20 \mathrm{GPa}$ 下で固相反応を誘発するため, 超伝導の測定はできなかった．極低温下で加王する場 合は化学反応が物さ光られるため, いままではっきり しなかった金属化や超伝導の研究が可能になる，中性 芳香族化合物の超伝導が見い出されれば，従来知られ ている有機超伝導体 (TMTSF) 2 X などとは異なった 挙動が考光られ, 大変興味深い. 特にペンタセンのよ うに芳香族炭化水素で超伝導が発見されたら，有機超 伝導体の世界も大きな広がりをるつよらになると思わ れる。

$t$-ポリアセチンンの吸収带は高压下でペンタセンと 同程度の大きな red shift を示すので, 金属化できる ように思觉るが, 静水圧下ですら反応する難点があ る. cisーポリアセチレンは高压下でもかなり安定であ るが, 圧力シフトはトランス型に比べて小さい。しか し極低温下で加圧したらシス型なら金属化されるかも 知れない，(CH) $\mathrm{X}_{n}$ の抵抗は加圧によりかなり減少 させられるが，低い圧力で固相反応を㮇起する，最近 導電性高分子の研究も飛躍的に増大しているから, 安 定な導電性高分子も合成されるであるう，そうなれば 高分子の超公導も見い出されるものと思われる.

Little が提案した高温超伝導体のモデル化合物で， ポリマー以外に 1 次元白金錯体がある ${ }^{19}$. この類似物 質として図 3 中の $\mathrm{Pt}(\mathrm{dmg})_{2}$ を選び，高圧下で電気 的, 光学的性質を調べると大变與味深い現象が見い出 された ${ }^{20)}$. $\operatorname{Pt}(\mathrm{dmg})_{2}$ は $d z^{2}$ 軌道が啮たされているた め大気圧下で $10^{15} \Omega \cdot \mathrm{cm}$ 之絶縁体であるが，約 6.7 $\mathrm{GPa}$ で粉末試料にもかかわらず $0.08 \Omega \cdot \mathrm{cm}$ になり， さらに加圧すると抵抗はゆっくりと増加する. この圧 力付近で圧力誘起吸収帯が観測される.これらの異常 が見られる圧力下での $\mathrm{Pt}-\mathrm{Pt}$ 間距離は KCP のそれ とほぼ等しい、ページ数も尽きたので詳しい話はでき ないが， $\mathrm{P} t(\mathrm{dmg})_{2}$ のふるすいは白金の $d$ 電子が配位 子と複雑な相互作用をしていることに起因する. 以上 の結果は Br のような酸化剤を用いなくとも, 配位子 をうまく選べば導電性錯体をつくれることを示唆して
いる．金属と配位子の相互作用を利用した新しい超伝 導体も決して夢物語ではないと思われる.

いままで述べてきたのは高圧下での研究が多かっ た. (TMTSF) ${ }_{2} \mathrm{PF}_{6}$ の超伝導が高圧下で初めて見い出 されたよらに，高圧力は原子間または分子間の相互作 用を強められるため, ある面で時代の先取りが可能で める. 特に低次元導体の研究汇は圧力は不可欠なるの と思われる，高圧下和よび大気圧下の合成と物性研究 を同時に進めることにより，いままでにない重要な有 機超伝導体がつくりだせるものと考える。

フルバレン骨格をもった有機超伝導体の設計は斉藤 によって詳しい解説が書かれているので，ここではほ とんどふれなかった，合わせて読んでいただければ幸 いである.

\section{文献}

1）山地邦楌: 応用物理, 53, 1090 (1984)

2) 斉藤軍治 : 固体物理, 19,797 (1984)

3) 石黒武彦, 安西弘行, 梶村皓二：応用物理, 50, 523 (1981)

4) 伝導性低次元物質の化学, 化学総説，42, 日本化 学会編 (1983)

5) 城谷一民, 川村春樹 : 分子構造討論会 (1978); 藤井源四郎, 城谷一民, 永野弘: 王力技術, 16, 281 (1978)

6) D. Jerome, A. Mazaud, M. Ribaut, K. Bechgaard: J. Phys. Lett., 41, 195 (1980)

7) H. Kawamura, I. Shirotani, K. Tachikawa: Solid State Comm., 49. 879 (1984)

8) H. Kawamura, I. Shirotani, O. Shimomura, S. Minomura, K. Tachikawa: Phys. Lett. 68A, 357 (1978)

9) W. A. Little: Phys. Rev., A134, 1416 (1964)

10) A. Brown, S. Rundqvist: Acta Cryst., 19, 684 (1965)

11) 城谷一民5：日本化学会誌, 1604 (1981)

12) J.C. Jamieson: Science, 139, 1291 (1963)

13) J. Wittig, BT. Matthias: Science, 160, 994 (1968)

14）川村春樹，下村 理，城谷一民，大刀川恭治：固 体物理, 19, 693 (1984)

15) I. Shirotani, A. Fukizawa, H. Kawamura, T. Yagi, S. Akimoto: Solid state Physics under Pressure, Ed. by S. Minomura, D. Reidel Publishing Co., 207 (1985)

16) S.S.P. Parkin, D. Jerome, K. Bechgaard: Mol. Cryst. Liq. Cryst., 79, 569 (1982)

17) R. B. Aust, W. H. Bentley, H. G. Drickamer : J. Chem. Phys., 1, 1856 (1964)

18) A. Onodera, I. Shirotani, H. Inokuchi, N. Kawai: Chem. Phys. Lett., 25, 296 (1974)

19) D. Davis, H. Gutfreund, W. A. Little: Phys. Rev., B13, 4766 (1976)

20) I. Shirotani, A. Onodera, Y. Hara: J. Solid. State Chem., 40, 180 (1981); 城谷一民 : 低温工 学, 12, 85 (1977) 